\title{
Estimation of Genetic Parameters for Maturity and Grain Yield in Diallel Crosses of Five Wheat Cultivars Using Two Different Models
}

\author{
Mahdiyeh Zare-kohan ${ }^{1} \&$ Bahram Heidari ${ }^{1}$ \\ ${ }^{1}$ Department of Crop Production and Plant Breeding, College of Agriculture, Shiraz University, Shiraz, Iran \\ Correspondence: Bahram Heidari, Department of Crop Production and Plant Breeding, College of Agriculture, \\ Shiraz University, P. O. Box 7144165186, Shiraz, Iran. E-mail: bheidari@shirazu.ac.ir
}

Received: April 11, 2012 Accepted: July 7, 2012 Online Published: July 11, 2012

doi:10.5539/jas.v4n8p74 URL: http://dx.doi.org/10.5539/jas.v4n8p74

\begin{abstract}
Wheat maturity is important for its adaptability to different environments and geographical regions. In order to obtain genetic information for maturity and grain yield, five wheat cultivars of Cross adl, Marvdasht, Chamran, Shiraz and Darab2 were crossed for producing one-way diallel crosses that were analyzed using two models of Griffing (1956) and Jinks and Hayman (1953). Parents and their $F_{2}$ progenies were cultivated at two locations of Shiraz and Zarghan, Iran, in 2010-2011. The traits of interest were days to heading (DDH) and maturity (DDM), grain filling duration (GFD), grain yield per plant (GY) and plant height $(\mathrm{PH})$. Genotype $\times$ location interaction was significant for PH and GFD but there was no interaction for DDH, DDM and GY. The variances due to general (GCA) and specific (SCA) combining abilities were significant for all the traits. Therefore, both additive and non-additive genetic components were not equally involved in genetic control of the characters studied. The GCA $\times$ location interaction was only significant for PH and GFD, an indication for the effects of environment on additive components. The Baker (1978) ratio for DDH (0.90 and 0.91 at Zarghan and Shiraz locations respectively), DDM (0.81 and 0.82) and GY (0.89 and 0.87) under both locations and for PH (0.88) at Shiraz showed the higher importance of additive variances in the genetic control of these traits. The GCA estimates revealed that Chamran for dwarfness, early heading and maturity and GFD, Darab2 for dwarfness, early heading and maturity, Marvdasht for GFD and GY were the best combiners. Graphical analysis and the average degree of dominance (less than 1) showed that gene action for all the traits was of partial dominance type.
\end{abstract}

Keywords: combining ability, diallel, gene action, maturity, grain yield, wheat

\section{Introduction}

Wheat maturity is a critical point for its adaptability to different environments. Early maturity is one of the most important objectives in wheat (Triticum aestivum L.) breeding programs at the latitudes with water limited conditions occurred during the middle and end of growing season. At the low latitudes, temperature and radiation do not vary much during wheat heading and grain filling time; therefore, earliness ensures timely crop harvest and protects plants from abiotic stresses such as drought (Poehlman \& Sleper, 1995). Early-matured cultivars may also be less prone to pre-harvest sprouting, which is an end-season phenomenon happened in humid conditions (Hucl \& Matus-Cadiz, 2002). In addition, under the areas with lower spring temperature that limits early growth, the short-season cultivars would place their reproductive growth under more favorable conditions than their long-season counterparts (Capristo et al., 2007).

Wheat developmental phases such as ear emergence, anthesis and maturity are controlled by three groups of vernalization ( $V r n)$, photoperiod (Ppd), and the earliness per se genes (Kosner \& Pankova, 1998) that their expression plays a significant role in wheat adaptation to different locations (Gororo et al., 2001). The Vrn and $P p d$ genes, respectively accounts for approximately $70-75 \%$ and $20-25 \%$ of the genetic variability of wheat heading date, while the contribution of earliness per se genes is about 5\% (Stelmakh, 1998).

Vernalization and photoperiod sensitivity protect delicate floral primordia from extreme temperatures via accelerated and/or delayed ear initiation (Law \& Worland, 1997). As a known phenomenon of vernalization, winter wheat requires exposure to a continuous cold condition prior to reproductive initiation. Spring wheat, generally does not have such a requirement, although some cultivars respond to cold via flowering early (Levy \& Peterson, 1972; Jedel et al., 1986; Iqbal et al., 2006). Although plants can respond to vernalization at any developmental stage (Flood \& Halloran, 1986), the effect is more pronounced during vegetative phases (Slafer \& 
Rawson, 1994). Selection for early flowering under non-vernalized conditions may aid in the breeding of vernalization non-responsive or early-matured spring cultivars (Iqbal et al., 2006). Photoperiod responsive genes play a key role in heading time under field conditions in the cultivars that have already been vernalized (Snape et al., 2001). Photoperiod has higher role in flowering of vernalization insensitive spring wheat than that of winter counterparts which respond to photoperiod when their vernalization requirement was fulfilled (Levy \& Peterson, 1972; Davidson et al., 1985).

Earliness per se is related to the difference in flowering time of plants that their vernalization and photoperiod requirements have been fulfilled (Kato et al., 2001). Photoperiod and vernalization responsive genes determine flowering time of wheat in response to day length and temperature; whereas, earliness per se genes control flowering time environmentally independent (Worland, 1996). Earliness per se is quantitatively controlled by a number of minor genes that their effects can be determined in the absence of vernalization and photoperiod genes effects (Kato \& Wada, 1999).

Genetic information of wheat flowering and maturity could aid orienting breeding strategies for short- or long-growing seasons. However, diallel crosses scheme is a useful mating design (Gardner \& Eberhart, 1966) that has been widely used to obtain information on the general (GCA) and the specific combining ability (SCA) of parental lines and their hybrid crosses in different crops (Xiang \& Li, 2001). Iqbal et al. (2007) working with five spring wheat genotypes found that GCA variances were significant for days to anthesis and maturity. Yan and Hunt (2002) evaluated the GCA of parents and the SCA of the crosses via a diallel design under multiple environments. The higher contribution of GCA effects has been linked to the additive effects that controlled expression of the traits in wheat (Kamaluddin et al., 2007). Kumar et al. (2011) identified the best specific and general combiners that were efficient for breeding days to flowering and grain yield per plant in seven bread wheat cultivars. In some studies (Klaimi \& Qualset, 1974; Edwards et al., 1976; Singh et al., 2003) the involvement of both additive and dominance gene actions was reported for genetic control of heading time in spring wheat, while in some other studies (Nanda et al., 1981; Bhatt, 1972; Sheikh et al., 2000; Iqbal et al., 2007; Kumar et al., 2011) additive gene actions were predominantly important.

Scanning literatures have showed that a better understanding of the underlying genetic control of agronomically important traits in spring wheat are useful in breeding for early maturity and grain yield. The present study was conducted to 1) investigate the relative importance of the GCA to SCA variances in genetic control of grain yield and maturity, and other agronomic traits using the $F_{2}$ wheat diallel crosses at two different locations, 2) identify the best general and specific combiners among different cultivars and crosses, and 3) perform graphical analysis of gene actions for the traits.

\section{Material and Methods}

Five wheat cultivars (Cross adl, Marvdasht, Chamran, Shiraz and Darab2) were selected (Table 1) to prepare $\mathrm{F}_{1}$ crosses based on a one-way diallel mating design. Ten $F_{1}$ seeds from each of the 10 crosses were grown and self pollinated in 2010 in a greenhouse to produce $F_{2}$ seeds. The seeds of $F_{2}$ progenies and their parents were cultivated at two locations of Zarghan Agricultural Research Station $\left(29^{\circ} 47^{\prime} \mathrm{N}, 52^{\circ} 43^{\prime} \mathrm{E}, 1600 \mathrm{~m}\right.$ alt $)$ and the Research Farm of College of Agriculture at Shiraz University (29 $50 \mathrm{~N}^{\prime}, 52^{\circ} 46^{\prime} \mathrm{E}, 1810 \mathrm{~m}$ alt), Iran in 2010-2011.

Table 1. Origin and pedigree of wheat cultivars used as parental genotypes for prepared diallel crosses

\begin{tabular}{lll}
\hline Cultivar & Origin & Pedigree \\
\hline Cross adl & Zarghan, Iran & Selected from farmers field \\
Marvdasht & Zarghan, Iran & HD2172/BLoudan//Azadi \\
Chamran & CIMMYT, Mexico & CM85836-5OY-OM-OY-3M-OY \\
Shiraz & Zarghan, Iran & Gv/D630//ALd"s"/3/Azd \\
Darab2 & CIMMYT, Mexico & Maya"s"/Nac \\
\hline
\end{tabular}

The seeds were sown on Nov. 20, 2010. At both locations, the experimental design was arranged as a randomized complete block design with three replications. The seeds were manually cultivated $5 \mathrm{~cm}$ apart in three 2-m long rows spaced $15 \mathrm{~cm}$ per plot. 
Ten plants in parental rows, and 30 ones from each $\mathrm{F}_{2}$ plots were randomly taken for traits measurements. The growing degree days (GDDs) were calculated for number of days from sowing to the heading time (DDH) and maturity (DDM).

The GDDs for grain filling period (GFD) was also calculated for the difference between days to heading and maturity. Plant height $(\mathrm{PH})$ was measured based on the height $(\mathrm{cm})$ from the ground level to the node below the spike. The mean grain weight per plant that was measured using selected plants in each plot was considered as the grain yield $(\mathrm{GY})$ of each $\mathrm{F}_{2}$ progenies or parental lines.

The data were tested for the normal distribution of frequency using Kolmogorov-smirnov test in SPSS software (SPSS, 2004). The data were subjected to an analysis of variance for a randomized complete block design and also a combined analysis of two locations was performed. Individual analyses of diallel for each trait within each location and a combined analysis across locations were conducted based on Griffing's method II, model I (Griffing, 1956a; 1956b). To estimate the GCA and SCA effects, a general linear model (GLM) procedure was used in SAS software (SAS Institute, 2003). The combining ability ratio was calculated according to Baker (1978) as follow:

$$
\text { Baker ratio }=\frac{2 \mathrm{MS}_{\mathrm{GCA}}}{2 \mathrm{MS}_{\mathrm{GCA}}+\mathrm{MS}_{\mathrm{SCA}}}
$$

Genetic parameters such as average degree of dominance, ratio of dominant to recessive alleles, number of effective factors, and the broad and narrow-sense heritability were estimated using Hayman and Jinks model (Jinks \& Hayman, 1953; Hayman, 1954 a \& b; Jinks, 1954). A graphical analysis was performed to determine the frequency of dominant and recessive alleles in the cultivars evaluated at the two locations. The validity of the required assumptions in Hayman (1954 a \& b) and Jinks (1954) model was tested using the regression coefficients of $\mathrm{Wr} / \mathrm{Vr}$ in Dial-98 (Ukai, 2006) and SAS softwares (SAS Institute, 2003). Genotypic correlation coefficients were computed for different traits under both locations using the SAS software (SAS Institute, 2003).

\section{Results and Discussions}

\subsection{Traits Mean and Diallel Variances}

Means for traits varied among cultivars and their crosses at both locations (Table 2). The lowest $(76.71 \mathrm{~cm})$ and highest $(118.32 \mathrm{~cm})$ plant height were belonged to the cultivar Darab 2 and the cross Marvdasht $\times$ Darab 2, respectively. DDH varied from 1453.2 to 1628.3 and the crosses showed lower DDH than their parental cultivars. Marvdasht $\times$ Darab 2 had the lowest DDM at Shiraz (2422.73) and Zarghan (2505.5) locations. Cross adl and Marvdasht had the highest GY at both locations. The average GY in the crosses involved either Cross adl or Marvdasht was relatively higher than that of other crosses.

Table 2. Traits mean in five parents and $\mathrm{F}_{2}$ progenies of wheat at Shiraz and Zarghan

\begin{tabular}{|c|c|c|c|c|c|c|c|c|c|c|}
\hline \multirow[b]{2}{*}{ Cultivar/Cross } & \multicolumn{2}{|l|}{$\mathrm{PH}(\mathrm{cm})$} & \multicolumn{2}{|l|}{$\mathrm{DDH}$} & \multicolumn{2}{|l|}{ DDM } & \multicolumn{2}{|l|}{ GFD } & \multicolumn{2}{|l|}{ GY(g) } \\
\hline & Zarghan & Shiraz & Zarghan & Shiraz & Zarghan & Shiraz & Zarghan & Shiraz & Zarghan & Shiraz \\
\hline Cross adl (1) & 105 & 91.8 & 1628.3 & 1589.3 & 2706.83 & 2618.97 & 1078.5 & 1029.67 & 23.92 & 22.11 \\
\hline Marvdasht (2) & 94.81 & 82.43 & 1543 & 1515.03 & 2684 & 2604.07 & 1141 & 1089.03 & 24.04 & 21.76 \\
\hline Chamran (3) & 84.13 & 78.86 & 1471.83 & 1458.13 & 2538 & 2455.23 & 1066.17 & 997.13 & 21.42 & 19.7 \\
\hline Shiraz (4) & 84.62 & 81.44 & 1569.3 & 1536.27 & 2629 & 2546.23 & 1059.67 & 1009.97 & 19.74 & 17.5 \\
\hline Darab 2 (5) & 80.12 & 76.71 & 1504.5 & 1485 & 2553.5 & 2470.17 & 1049 & 985.17 & 17.91 & 16.35 \\
\hline $1 \times 2$ & 108.25 & 93.22 & 1531.5 & 1507.13 & 2584.83 & 2501.03 & 1053.3 & 993.9 & 22.71 & 21.18 \\
\hline $1 \times 3$ & 94.13 & 92.86 & 1518.3 & 1495.2 & 2636 & 2553.97 & 1117.67 & 1058.77 & 21.15 & 18.58 \\
\hline $1 \times 4$ & 104.15 & 98 & 1524.83 & 1501.13 & 2643.83 & 2561.13 & 1119 & 1060 & 19.96 & 17.38 \\
\hline $1 \times 5$ & 111.12 & 88.13 & 1491.3 & 1473.07 & 2513.67 & 2432.73 & 1022.3 & 959.67 & 23.74 & 22.19 \\
\hline $2 \times 3$ & 99.12 & 80.2 & 1478.67 & 1463.2 & 2569.5 & 2485.83 & 1090.83 & 1022.63 & 18.11 & 16.35 \\
\hline $2 \times 4$ & 94.77 & 79.17 & 1524.3 & 1500.3 & 2599.17 & 2516.1 & 1074.83 & 1015.83 & 19.31 & 17.2 \\
\hline $2 \times 5$ & 118.32 & 87 & 1485 & 1468.13 & 2505.5 & 2422.73 & 1020.5 & 954.6 & 18.73 & 16.5 \\
\hline $3 \times 4$ & 104.47 & 90.1 & 1498.17 & 1480.07 & 2591.3 & 2508.77 & 1093.17 & 1028.7 & 17.61 & 15.95 \\
\hline $3 \times 5$ & 89.68 & 81.87 & 1465.5 & 1453.2 & 2577 & 2493.7 & 1111.5 & 1040.5 & 17.62 & 15.66 \\
\hline $4 \times 5$ & 104.21 & 79.7 & 1491.3 & 1473.07 & 2584.83 & 2501.03 & 1093.5 & 1027.97 & 16.29 & 16.31 \\
\hline
\end{tabular}

PH: plant height, DDH: degree day to heading, DDM: degree day to maturity, GFD: grain filling period, GY: Grain yield per plant 
Combined analyses of variances showed significant effect of genotype indicating variation among parents and crosses at the two locations (Table 3 ). Genotype $\times$ location interaction was significant for PH and GFD showing that expression of these traits was location-dependent (Eberhart \& Russell, 1966). On the other hand, for DDH, DDM and GY, the non-significant genotype by location variance showed that the behavior of the genotypes, cultivars and their crosses, was relatively similar at both locations. The mean squares of combining abilities revealed that the variance due to GCA and SCA were significant for all the traits at both locations (Table 3). Therefore, both additive and non-additive gene effects were involved in genetic control of all the traits. The GCA $\times$ location was significant for PH and GFD, reflecting the significant effects of environment on additive gene actions. Except for PH, the SCA $\times$ location interaction was not significant for evaluated traits.

Table 3. Combined analysis of variances for the effects of location, genotype, general (GCA) and specific (SCA) combining abilities and their interactions in five wheat cultivars and their crosses

\begin{tabular}{|c|c|c|c|c|c|c|}
\hline \multirow[b]{2}{*}{ Effect } & \multirow[b]{2}{*}{ Df } & \multicolumn{5}{|c|}{ Mean squares } \\
\hline & & $\mathrm{PH}(\mathrm{cm})$ & $\mathrm{DDH}$ & DDM & GFD & GY(g) \\
\hline Location (L) & 1 & $3818.51^{* *}$ & $10743.1^{* *}$ & $155077.21 * *$ & $84174.5^{* *}$ & $75.88^{* *}$ \\
\hline Genotype (G) & 14 & $367.64 * *$ & $9002.18^{* *}$ & $19758.33^{* *}$ & $7692.57 * *$ & $36.55^{* *}$ \\
\hline GCA & 4 & $520.68 * *$ & $21140.15^{* *}$ & $33514.7 * *$ & $5787.96^{* *}$ & $78.55^{* *}$ \\
\hline SCA & 10 & $306.42 * *$ & $4147^{* *}$ & $14255.78^{* *}$ & $8454.42 * *$ & $19.74 * *$ \\
\hline $\mathrm{G} \times \mathrm{L}$ & 14 & $115.26^{* *}$ & $79.62^{\text {n.s }}$ & $4.36^{\text {n.s }}$ & $84.24 *$ & $0.58^{\text {n.s }}$ \\
\hline $\mathrm{GCA} \times \mathrm{L}$ & 4 & $95.93 * *$ & $194.22^{\mathrm{n} . \mathrm{s}}$ & $4.09^{\mathrm{n} . \mathrm{s}}$ & $168.79 * *$ & $0.37^{\mathrm{n} . \mathrm{s}}$ \\
\hline $\mathrm{SCA} \times \mathrm{L}$ & 10 & $122.99 * *$ & $33.78^{\mathrm{n} . \mathrm{s}}$ & $4.46^{\mathrm{n} . \mathrm{s}}$ & $30.81^{\mathrm{n} . \mathrm{s}}$ & $0.67^{\mathrm{n} . \mathrm{s}}$ \\
\hline Error & 56 & 0.12 & 539.3 & 828.34 & 44.47 & 1.59 \\
\hline
\end{tabular}

PH: plant height, DDH: degree day to heading, DDM: degree day to maturity, GFD: grain filling period, GY:

Grain yield per plant, * and ** respectively significant at 0.05 and 0.01 probability levels

\subsection{Baker Ratio}

Baker ratio (Baker, 1978) for DDH, DDM and GY at both locations and for PH at Shiraz showed the importance of additive gene effects in the genetic control of these traits (Table 4). The same result was reported in other works on wheat (Khalifa, 1998; Zhang et al., 1985; Iqbal et al., 2006; Bhatia et al., 1979; Sing \& Paroda, 1986). For GFD under both locations and PH at Zarghan, the Baker ratio indicated the importance of non-additive gene effects. Preponderance of non-additive effects contributed to genetic control of GFP and PH has been reported by Shahzad and Chowdhary (1998) and Iqbal et al. (2007).

Table 4. Mean squares for general (GCA) and specific (SCA) combining abilities and the Baker ratio at two locations

\begin{tabular}{|c|c|c|c|c|c|c|c|c|c|c|c|}
\hline \multirow{2}{*}{ Effect } & \multirow{2}{*}{ Df } & \multicolumn{2}{|l|}{$\mathrm{PH}(\mathrm{cm})$} & \multicolumn{2}{|l|}{$\mathrm{DDH}$} & \multicolumn{2}{|l|}{ DDM } & \multicolumn{2}{|l|}{ GFD } & \multicolumn{2}{|l|}{$\mathrm{GY}(\mathrm{g})$} \\
\hline & & Zarghan & Shiraz & Zarghan & Shiraz & Zarghan & Shiraz & Zarghan & Shiraz & Zarghan & Shiraz \\
\hline GCA & 4 & $344.1 * *$ & $272.51 * *$ & $12677.9^{* *}$ & $8656.46^{* *}$ & $16921.13 * *$ & $16597.67 * *$ & $2620.23 * *$ & $3336.51 * *$ & $43.2 * *$ & $35.73 * *$ \\
\hline SCA & 10 & $357.76^{* *}$ & $71.65 * *$ & $2457.4^{* *}$ & $1723.38 * *$ & $7167.6^{* *}$ & $7092.64 * *$ & $4139.55^{* *}$ & $4345.69 * *$ & $10.1 * *$ & $10.32 * *$ \\
\hline Error & 28 & 0.063 & 0.02 & 215.26 & 144.27 & 268.24 & 284 & 5.23 & 24.42 & 0.32 & 0.74 \\
\hline $\begin{array}{c}\text { Baker } \\
\text { ratio }\end{array}$ & & 0.66 & 0.88 & 0.91 & 0.90 & 0.81 & 0.82 & 0.56 & 0.61 & 0.89 & 0.87 \\
\hline
\end{tabular}

PH: plant height, DDH: degree day to heading, DDM: degree day to maturity, GFD: grain filling period, GY: Grain yield per plant, * and ** respectively significant at 0.05 and 0.01 probability levels, ns: not significant 


\subsection{General and Specific Combining Abilities}

The GCA estimates revealed that the cultivars Chamran, Shiraz and Darab2 were the best combiners for PH and consequently for dwarfness at both locations (Table 5). The cultivars Chamran and Darab2 with significantly negative GCA effects decreased number of days to heading and maturity in their progenies. Shiraz, Chamran and Marvdasht for GFD and Marvdasht and Cross adl for GY were found to be as the best combiners for increasing these traits. Darab2 was found to be a negative combiner for all traits except for GY at Shiraz, while Cross adl and Marvdasht had positive GCAs for most of the traits. High GCA effects are related to additive or additive $\times$ additive interaction effects (Griffing, 1956a \& 1956b), the components that respond to selection. Therefore, the cultivars with negative GCAs increase selection efficiency in breeding programs for earliness in wheat. Our results showed that Darab2 and Chamran could extensively be utilized in the hybridization programs in order to accelerate the pace of genetic improvement of earliness in bread wheat.

Table 5. The general (GCA) and specific (SCA) combining abilities effects of wheat cultivars and their crosses at Shiraz and Zarghan

\begin{tabular}{|c|c|c|c|c|c|c|c|c|c|c|}
\hline \multirow[b]{2}{*}{ Cultivar/Cross } & \multicolumn{2}{|l|}{$\mathrm{PH}(\mathrm{cm})$} & \multicolumn{2}{|l|}{$\mathrm{DDH}$} & \multicolumn{2}{|l|}{ DDM } & \multicolumn{2}{|l|}{ GFD } & \multicolumn{2}{|l|}{ GY (g) } \\
\hline & Zarghan & Shiraz & Zarghan & Shiraz & Zarghan & Shiraz & Zarghan & Shiraz & Zarghan & Shiraz \\
\hline Cross adl (1) & $5.27 * *$ & $6.17 * *$ & $33.18 * *$ & $27.98 * *$ & $32.17 * *$ & $31.16^{*}$ & -1.00 & 3.18 & $2.07 * *$ & $1.95 * *$ \\
\hline Marvdasht (2) & $2.76^{* *}$ & $-1.2 * *$ & 2.16 & 1.36 & 8.6 & 9.31 & $6.44 * *$ & $7.95 * *$ & $0.86^{* *}$ & $0.69 *$ \\
\hline Chamran (3) & $-5.01 * *$ & $-1.4 * *$ & $-26.58 * *$ & $-21.62 * *$ & $-16.71^{*}$ & $-16.56^{*}$ & $9.87 * *$ & $5.06^{*}$ & $-0.51 *$ & -0.56 \\
\hline Shiraz (4) & $-1.99 *$ & $-0.39 * *$ & $12.42 *$ & $9.68 *$ & $15.77^{*}$ & $15.83^{*}$ & $3.35^{*}$ & $6.14 *$ & $1.18^{* *}$ & $-1.15^{*}$ \\
\hline Darab2 (5) & $-1.03 * *$ & $-3.21 * *$ & $-21.18^{*}$ & $-17.4^{*}$ & $-39.83 * *$ & $-39.73 * *$ & $-18.65^{* *}$ & $-22.33 * *$ & $-1.24 * *$ & $0.93 *$ \\
\hline $1 \times 2$ & $1.76^{* *}$ & $2.77 * *$ & -18.9 & -15.42 & $-50.4 *$ & $-50.88 *$ & $-31.5^{* *}$ & $-35.46^{* *}$ & -0.37 & 0.22 \\
\hline $1 \times 3$ & $-4.58 * *$ & $2.66^{* *}$ & -3.3 & -4.37 & 26.07 & 27.92 & $29.4 * *$ & $32.29 * *$ & -0.56 & -1.13 \\
\hline $1 \times 4$ & $2.4 * *$ & $6.79 * *$ & $-35.83 *$ & $-29.75^{*}$ & 1.43 & 2.69 & $37.26^{* *}$ & $32.44 * *$ & $-1.08^{*}$ & $-1.74 *$ \\
\hline $1 \times 5$ & $4.42 * *$ & $-6.24 * *$ & 11.17 & 9.41 & -25.12 & -24.94 & $-36.28 * *$ & $-34.34 * *$ & $2.39 * *$ & $2.75 *$ \\
\hline $2 \times 3$ & $2.91 * *$ & $-2.66 * *$ & -11.98 & -9.75 & -16.86 & -18.36 & $-4.9 *$ & -8.61 & $-2.39 * *$ & $-2.09 *$ \\
\hline $2 \times 4$ & $-4.46^{* *}$ & $-4.7 * *$ & -5.31 & -3.96 & -19.67 & -20.48 & $-14.36^{* *}$ & $16.5^{*}$ & -0.52 & -0.66 \\
\hline $2 \times 5$ & $8.96 * *$ & $5.26 * *$ & 12.57 & 10.05 & 14.6 & 15.72 & 2.02 & 5.66 & $1.12 *$ & 0.48 \\
\hline $3 \times 4$ & $13.01 * *$ & $6.47 * *$ & -2.74 & -1.21 & -2.2 & -1.95 & 0.55 & -0.75 & -0.85 & -0.65 \\
\hline $3 \times 5$ & $-7.04 * *$ & $-2.7 * *$ & 8.12 & 7.17 & 16.02 & 15.47 & $7.9^{*}$ & 8.3 & $1.51 *$ & 1.36 \\
\hline $4 \times 5$ & $-1.09 * *$ & $-5.34 * *$ & 14.45 & 11.25 & 17.43 & 16.61 & 2.98 & 5.36 & 0.51 & $1.56^{*}$ \\
\hline $\mathrm{SEg}_{\mathrm{i}}$ & 0.085 & 0.044 & 4.96 & 4.06 & 5.54 & 5.69 & 0.77 & 1.67 & 0.192 & 0.29 \\
\hline $\mathrm{SEs}_{\mathrm{ij}}$ & 0.218 & 0.114 & 12.81 & 10.48 & 14.3 & 14.71 & 1.99 & 4.31 & 0.496 & 0.75 \\
\hline
\end{tabular}

PH: plant height, DDH: degree day to heading, DDM: degree day to maturity, GFD: grain filling period ,GY: Grain yield per plant, * and ** respectively significant at 0.05 and 0.01 probability levels, $\mathrm{SEg}_{\mathrm{i}}$ and $\mathrm{SEs}_{\mathrm{ij}}$ denote for standard error for general and specific combining ability effects respectively 
Table 6. Estimated genetic parameters for the traits in wheat diallel crosses evaluated at Shiraz and Zarghan

\begin{tabular}{|c|c|c|c|c|c|c|c|c|c|c|}
\hline \multirow[b]{3}{*}{ Parameter } & \multicolumn{10}{|l|}{ Trait } \\
\hline & \multicolumn{2}{|l|}{$\mathrm{PH}(\mathrm{cm})$} & \multicolumn{2}{|l|}{$\mathrm{DDH}$} & \multicolumn{2}{|l|}{$\mathrm{DDM}^{*}$} & \multicolumn{2}{|l|}{ GFD } & \multicolumn{2}{|l|}{ GY (g) } \\
\hline & Zarghan & Shiraz & Zarghan & Shiraz & Zarghan & Shiraz & Zarghan & Shiraz & Zarghan & Shiraz \\
\hline $\mathrm{D}$ & 125.5 & 44.4 & 3437.51 & 2393.61 & - & 2789.92 & - & - & 6.73 & 5.8 \\
\hline $\mathrm{H}_{1}$ & 377.77 & 50.68 & 1962.83 & 1410.98 & - & 1475.07 & - & - & 11.97 & 11.6 \\
\hline $\mathrm{H}_{2}$ & 335.98 & 48.8 & 1741.65 & 1233.87 & - & 1383.54 & - & - & 9.24 & 9.15 \\
\hline $\mathrm{F}$ & 37.15 & -11.7 & 1721.95 & 1257.79 & - & 1327.2 & - & - & 0.084 & 0.81 \\
\hline$h^{2}$ & 370.1 & 51.02 & 4512.92 & 3114.99 & - & 2425.72 & - & - & 8.89 & 7.49 \\
\hline$\left(\mathrm{H}_{1} / 4 \mathrm{D}\right)^{0.5}$ & 0.87 & 0.53 & 0.38 & 0.38 & - & 0.36 & - & - & 0.67 & 0.71 \\
\hline$\frac{K_{D}}{K_{R}}=\frac{\sqrt{4 D H_{1}}+F}{\sqrt{4 D H_{1}}-F}$ & 1.19 & 0.78 & 1.99 & 2.04 & - & 1.97 & - & - & 1 & 1.1 \\
\hline $4 \mathrm{~h}^{2} / \mathrm{H}_{2}$ & 4.41 & 4.18 & 10.36 & 10.1 & - & 7.01 & - & - & 3.85 & 3.28 \\
\hline $\mathrm{R}(\mathrm{Wr}+\mathrm{Vr}), \mathrm{Yr}$ & 19.24 & 7.14 & -67.99 & -56.47 & - & -50.27 & - & - & -3.01 & -2.8 \\
\hline $\mathrm{H}_{2} / 4 \mathrm{H}_{1}$ & 0.22 & 0.24 & 0.22 & 0.22 & - & 0.23 & - & - & 0.19 & 0.2 \\
\hline $\mathrm{H}_{1}-\mathrm{H}_{2}$ & 41.79 & 1.88 & 221.18 & 177.11 & - & 91.53 & - & - & 2.73 & 2.45 \\
\hline $\mathrm{h}_{\mathrm{b}}^{2}$ & 0.99 & 0.99 & 0.88 & 0.88 & - & 0.88 & - & - & 0.93 & 0.84 \\
\hline $\mathrm{h}_{\mathrm{n}}^{2}$ & 0.74 & 0.89 & 0.81 & 0.81 & - & 0.82 & - & - & 0.8 & 0.71 \\
\hline
\end{tabular}

D:additive effect, $\mathrm{H}_{1}$ and $\mathrm{H}_{2}$ : dominance effects, $\mathrm{F}$ : frequency of dominant to recessive alleles in parents, $\mathrm{h}^{2}$ : overall dominance effect due to heterozygous loci, $\left(\mathrm{H}_{1} / 4 \mathrm{D}\right)^{0.5}$ : average degree of dominance, $\left[(4 \mathrm{DH} 1)^{1 / 2}+\right.$ $\left.\mathrm{F} /(4 \mathrm{DH} 1)^{1 / 2}-\mathrm{F}\right]$ : proportion of dominant and recessive genes in the parents, $4 \mathrm{~h}^{2} / \mathrm{H}_{2}$ : number of effective factors (genes), $\mathrm{H}_{2} / 4 \mathrm{H}_{1}$ : proportion of genes with positive and/or negative effects in the parents, $\mathrm{h}_{\mathrm{b}}^{2}$ : broad - sense heritability, $\mathrm{h}_{\mathrm{n}}^{2}$ : narrow- sense heritability, PH: plant height, DDH: degree day to heading, DDM: degree day to maturity, GFD: grain filling period, GY: Grain yield per plant, *: assumptions for Hayman (1954a \& 1954b) and Jinks (1954) models were not valid for DDM at Zarghan and for GFD under both locations, therefore parameters were not estimated

Almost similar trends were observed for the specific combining ability of crosses at both environments. The SCAs (Table 5) for wheat crosses revealed that among crosses, the crosses Chamran $\times$ Darab2 and Shiraz $\times$ Darab2 for dwarfness, GFD and GY, Cross adl $\times$ Marvdasht for early maturity, Cross adl $\times$ Shiraz for early heading and GFD, Cross adl $\times$ Darab2 for grain yield and Marvdasht $\times$ Shiraz for dwarfness were the best specific combiners. In self-pollinated crops such as wheat, the crosses with appropriate specific combining abilities are useful genetic materials for selection of superior recombinations and plants as a consequence of segregation in progeny generation.

\subsection{Validity of the Assumptions for Hayman and Jinks Model}

The validity of required assumptions underlying the genetic model for diallel crosses tested via analysis of variance for $(\mathrm{Wr}+\mathrm{Vr})$ and $(\mathrm{Wr}-\mathrm{Vr})$ and the results indicated that the assumptions were adequate for DDH and GY. Assumptions for PH at both locations and for DDM only at Shiraz were not valid; therefore, data transformation and/or removing one of the parents from the analysis aided the assumptions to be fulfilled. For GFD at both locations and DDM at Zarghan even eliminating the parents was not efficient for validity of the assumptions.

\subsection{Graphical Analysis and Genetic Parameters}

The $\mathrm{H}_{1}-\mathrm{H}_{2}$ indicated the unequal distribution of dominant and recessive alleles for all traits in the parents, a result that was strengthened by the ratio $\mathrm{H}_{2} / 4 \mathrm{H}_{1}$, that was lower than 0.25 at both locations (Table 6). The negative $\mathrm{F}$-value and the ratio $\left[\left(4 \mathrm{DH}_{1}\right)^{1 / 2}+\mathrm{F} /\left(4 \mathrm{DH}_{1}\right)^{1 / 2}-\mathrm{F}\right]$ that was lower than 1 indicated the predominance of recessive alleles in controlling $\mathrm{PH}$ in parental wheat cultivars at Shiraz. Regarding the other traits, the positive F-values at both locations suggested that dominant alleles were more abundant than the recessives ones. 
For all traits at both locations, the $\mathrm{Wr} / \mathrm{Vr}$ graph showed that the regression line crossed the $\mathrm{Wr}$-axis at the positive part, which is an indication for the incomplete or partial dominance gene action (Figures 1 to 7). This result was confirmed by dominance ratio $\left(\mathrm{H}_{1} / \mathrm{D}\right)^{0.5}$ that was less than 1 . Similar results indicated that partial dominance was responsible for traits such as plant height (Akhtar \& Chowdhry, 2006; Ullah, et al., 2010; Gorjanovic \& Balalic, 2005; Inamullah et al., 2005) and wheat maturity (Rahman et al., 2003). Grain yield has been reported to be controlled by both additive (Ullah, et al., 2010; Habib \& Khan, 2003; Mahmood et al., 2003; Riaz \& Chowdhry, 2003) and dominance effects (Ojaghi \& Akhundova, 2010).

The correlation of $(\mathrm{Wr}+\mathrm{Vr})$ and $\mathrm{Yr}$, which was lower than zero showed that for DDH, DDM and GY, the genes with increasing effects on the traits were often of dominance, whereas for $\mathrm{PH}$, the recessive alleles increased this trait. Based on graphical analysis in Hayman and Jinks model (Jinks \& Hayman, 1953; Hayman, 1954 a \& b; Jinks, 1954) and distribution of the parental lines over the curve of $\mathrm{Wr}$ and $\mathrm{Vr}$, the closer cultivars to the cross point of the axes have relatively more dominant alleles, while the farthest ones would frequently have recessive genes for the trait of interest. Therefore, Figures 1 and 2 indicated that for PH, the cultivars Chamran and Cross adl at Zarghan experiment and Cross adl at Shiraz location had the most dominant genes, while Darab2 at Zarghan and Chamran at Shiraz experiment - being the farthest from the origin of regression graph - had the most recessive genes. Chamran and Darab2 had the most dominant alleles for DDH at both locations, while Cross adl had the highest frequencies for recessive genes (Figure 3-4). The distribution of the cultivars over the regression line for GY was similar under both locations and the parental cultivars such as Chamran, Marvdasht and Cross adl had the highest frequency of dominant genes for controlling grain yield in their crosses (Figure 5-6). Graphical analysis showed that Chamran and Cross adl respectively had frequent dominant and recessive genes for DDM under Shiraz location (Figure 7). The broad and narrow-sense heritabilities of all traits were relatively high; therefore selection strategies for the best combiners that improve the traits of interest would be efficient.

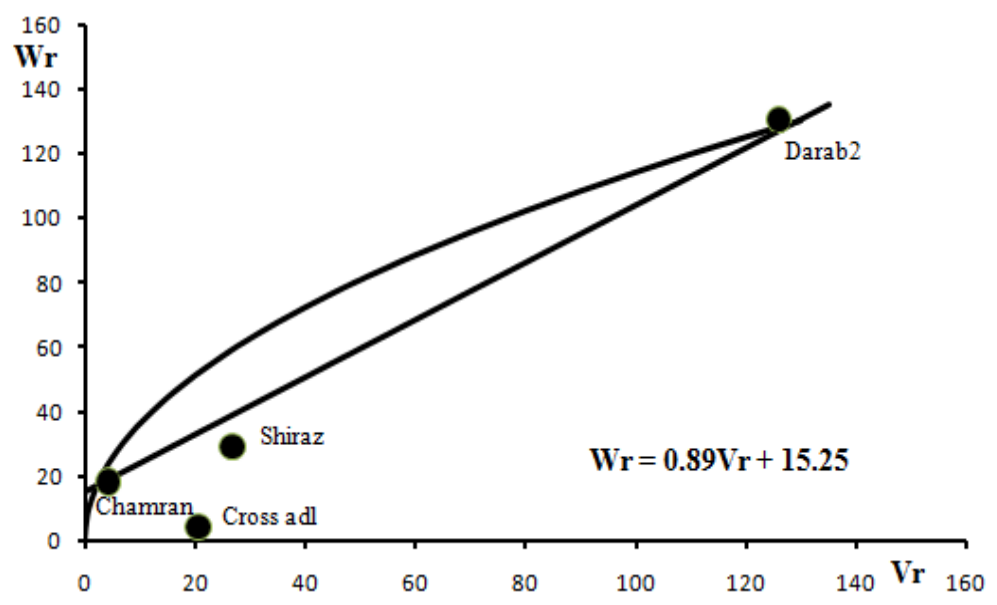

Figure 1. Covariance/Variance $(\mathrm{Wr} / \mathrm{Vr})$ graph for plant height at Zarghan region

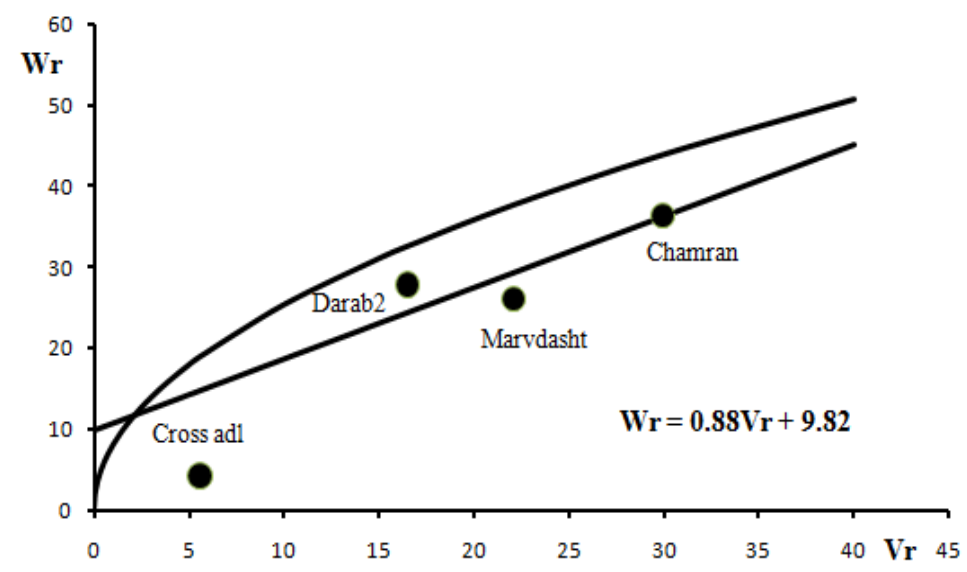

Figure 2. Covariance/Variance ( $\mathrm{Wr} / \mathrm{Vr}$ ) graph for plant height at Shiraz region 


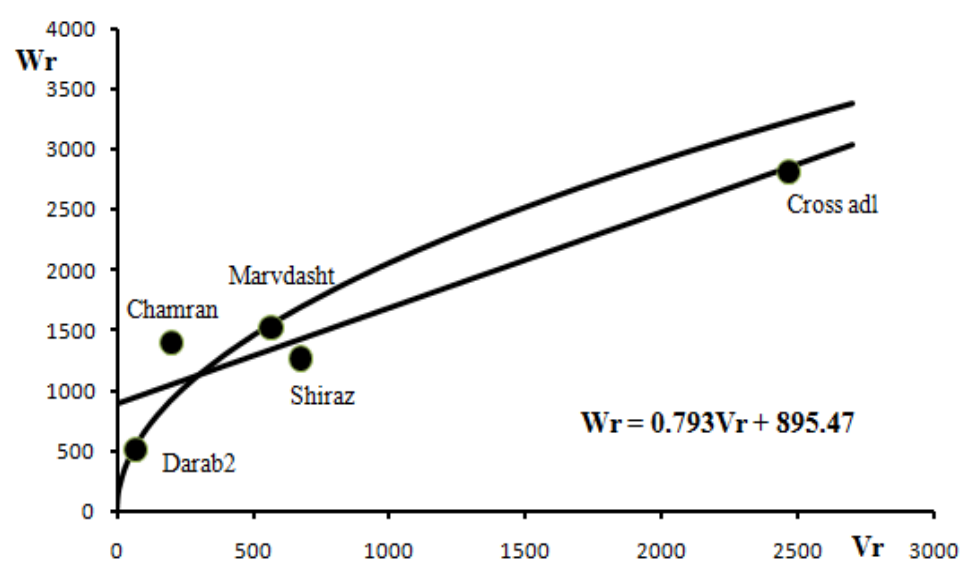

Figure 3. Covariance/Variance ( $\mathrm{Wr} / \mathrm{Vr}$ ) graph for degree day to heading at Zarghan

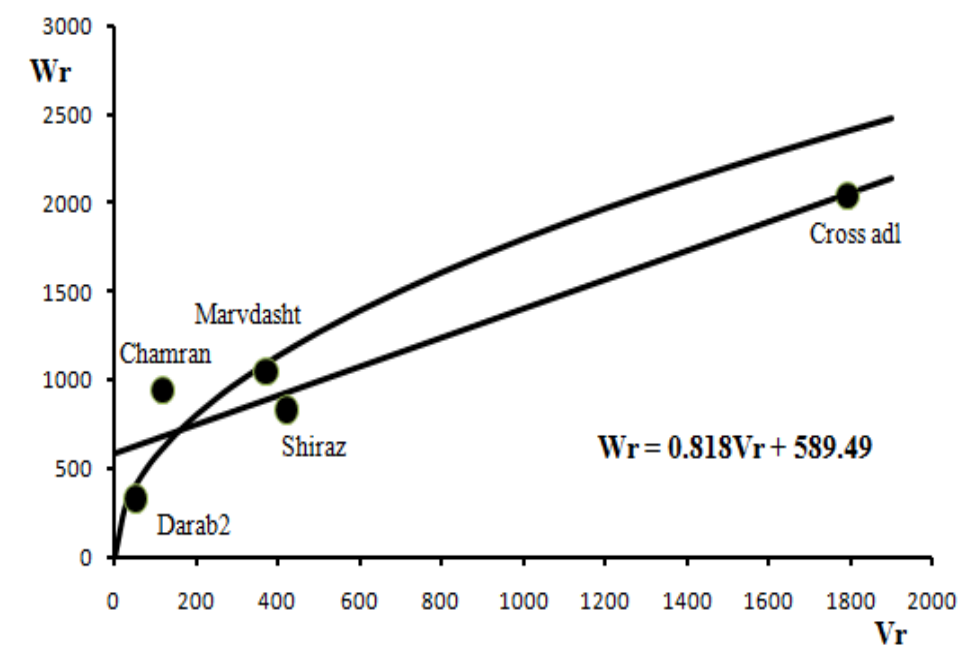

Figure 4. Covariance/Variance ( $\mathrm{Wr} / \mathrm{Vr}$ ) graph for degree day to heading at Shiraz

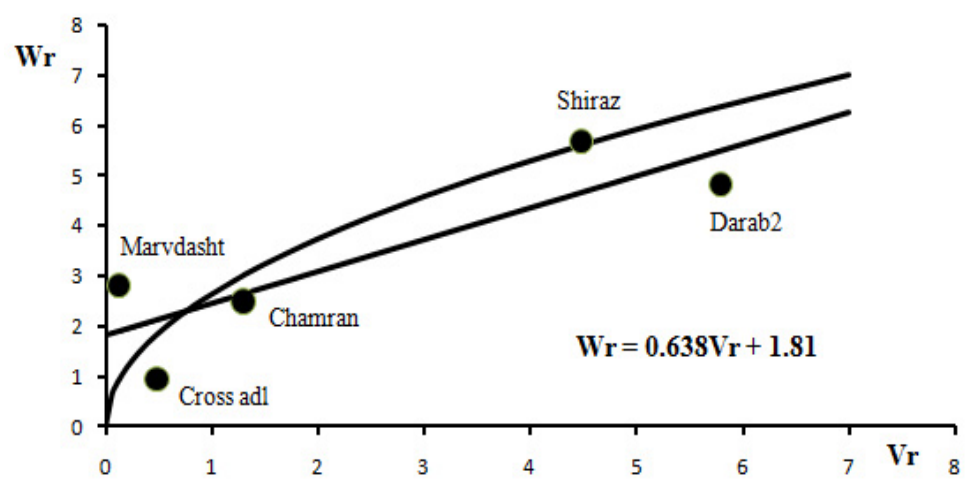

Figure 5. Covariance/Variance ( $\mathrm{Wr} / \mathrm{Vr})$ graph for grain yield at Zarghan 


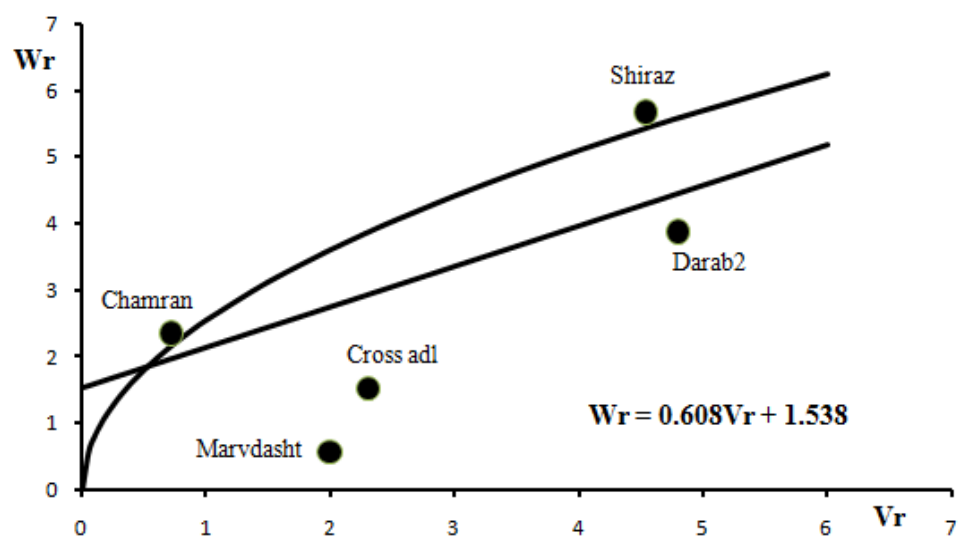

Figure 6. Covariance/Variance (Wr/Vr) graph for grain yield at Shiraz

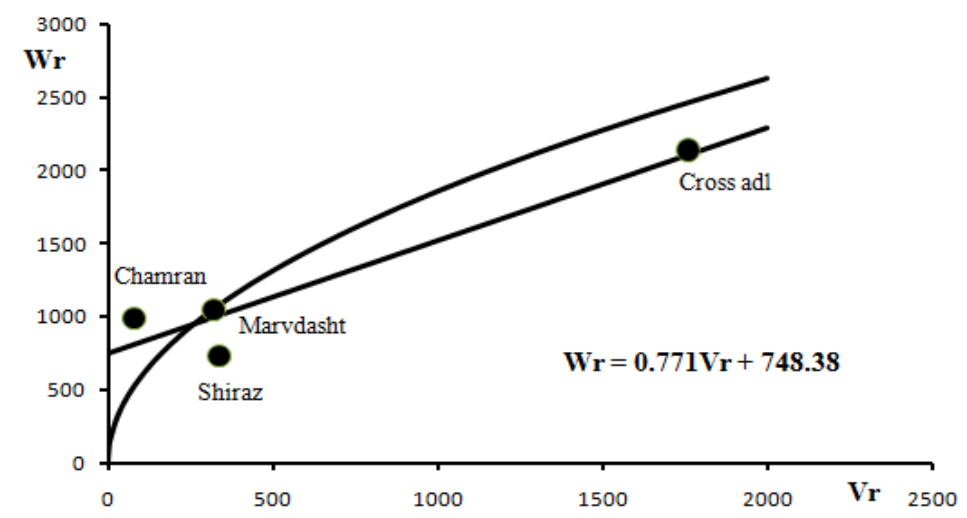

Figure 7. Covariance/Variance (Wr/Vr) graph for degree day to maturity at Shiraz

\subsection{Genetic Correlation Coefficients}

Genetic correlation coefficients among traits are presented in Table 7. GY was significantly correlated with $\mathrm{DDH}\left(\mathrm{r}=0.58^{*}\right.$ and $0.59^{*}$ at Zarghan and Shiraz, respectively), while its correlation with DDM $\left(\mathrm{r}_{\mathrm{Zarghan}}=0.39\right.$, $\mathrm{r}_{\text {Shiraz }}=0.36$ ) was not significant. The correlations calculated between DDM and GFD was significantly positive $\left(\mathrm{r}_{\text {Zarghan }}=0.70^{* *}, \mathrm{r}_{\text {Shiraz }}=0.81^{* *}\right)$ showing that late-flower plants had a prolonged grain filling, while the early flowers used the nutrients and resources in a shorter period of time during their growth. The genetic correlation coefficients showed that grain yield was reduced in early-heading wheat plants.

Table 7. Genetic correlation coefficients between traits in bread wheat cultivar and crosses at Shiraz and Zarghan

\begin{tabular}{lllllllll}
\hline \multirow{2}{*}{ Traits } & DDH & & DDM & \multicolumn{2}{c}{ GFD } & \multicolumn{3}{c}{ GY $(\mathrm{g})$} \\
\cline { 2 - 8 } & Zarghan & Shiraz & Zarghan & Shiraz & Zarghan & Shiraz & Zarghan & Shiraz \\
\hline PH & 0.025 & 0.37 & 0.018 & 0.34 & -0.26 & 0.18 & 0.16 & 0.35 \\
DDH & & & $0.77^{* *}$ & $0.71^{* *}$ & 0.087 & 0.24 & $0.58^{*}$ & $0.59^{*}$ \\
DDM & & & & & $0.7^{* *}$ & $0.81^{* *}$ & 0.39 & 0.36 \\
GFD & & & & & & & -0.04 & 0.01 \\
GY & & & & & & & &
\end{tabular}

PH: plant height, DDH: degree day to heading, DDM: degree day to maturity, GFD: grain filling period, GY: Grain yield per plant, * and ** respectively significant at 0.05 and 0.01 probability levels 


\section{Conclusions}

Our findings showed that the results of both Griffing (1956 a \& b) and Hayman (1954 a \& b) and Jinks (1954) models were consistent and that both additive (fixable) and non-additive (non-fixable) components of genetic variances were involved in governing the inheritance of almost all the traits, although the contribution of additive genetic variance was predominant. Therefore, bi-parental and/or diallel mating design that allow inter-mating the selected plants in different cycles and exploit both additive and non-additive gene effects could be useful in the genetic improvement of the characters in bread wheat. In present study we found that all traits except GFD were predominantly controlled by additive gene effects and the broad and narrow-sense heritabilities were relatively high under both locations. Therefore, selection for early heading/maturity in early generations increases genetic improvement towards earliness, but selection for GFD that was mainly controlled via non-additive gene effects must be postponed until the advanced generations.

General combining ability estimates revealed that among the cultivars, Chamran for dwarfness, early heading and maturity and GFD, Darab2 for dwarfness, early heading and maturity, Marvdasht for GFD and GY were the best general combiners that can be used in breeding programs. The estimated SCAs revealed that selection in the segregated progenies of Chamran $\times$ Darab2 and Shiraz $\times$ Darab2 for dwarfness, GFD and GY, Cross adl $\times$ Marvdasht for early maturity and Cross adl $\times$ Shiraz for early heading and GFD would be efficient for breeding purposes for related traits.

\section{References}

Akhtar, N., \& Chowdhry, M. A. (2006). Genetic analysis of yield and some other quantitative traits in bread wheat. International Journal of Agriculture and Biology, 4, 523-527.

Baker, R. J. (1978). Issues in diallel analysis. Crop Science, 18, 533-536.

Bhatia, A., Bhuller, G. S., \& Gill, K. S. (1979). Combining ability in durum wheat (Triticum durum Desf.). Cereal Research Communications, 17(1), 49-51.

Bhatt, G. M. (1972). Inheritance of heading date, plant height, and kernel weight in two spring wheat crosses. Crop Science, 12, 95-98.

Capristo, P. R., Rizalli, R. H., \& Andrade, F. H. (2007). Ecophysiological yield components of maize hybrids with contrasting maturity. Agronomy Journal, 99, 1111-1118. http://dx.doi.org.10.2134/agronj2006.0360

Davidson, J. L., Christian, K. R., Jones, D. B., \& Bremner, P. M. (1985). Responses of wheat to vernalization and photoperiod. Australian Journal of Agricultural Research, 36, 347-359.

Eberhart, S. A., \& Russel, W. A. (1966). Stability parameters for comparing varieties. Crop Science, 6, 36-40.

Edwards, L. H., Ketata, H., \& Smith, E. L. (1976). Gene action of heading date, plant height, and other characters in two winter wheat crosses. Crop Science, 16, 275-277.

Flood, R. G., \& Halloran, G. M. (1986). Genetics and physiology of vernalization response in wheat. Advances in Agronomy, 39, 87-124. http://dx.doi.org/10.1016/S0065-2113(08)60466-6.

Gardner, C. O., \& Eberhart, S. A. (1966). Analysis and interpretation of the variety cross diallel and related populations. Biometrics, 22, 439-452.

Gororo, N. N., Flood, R. G., Eastwood, R. F., \& Eagles, H. A. (2001). Photoperiod and vernalization responses in $T$. turgidum $\times T$. tauschii synthetic hexaploid wheats. Annals of Botany, 88, 947-952. http://dx.doi.org/10.1006/anbo.2001.1531

Griffing, B. (1956a). A generalized treatment of the use of diallel crosses in quantitative inheritance. Heredity, $10,31-50$.

Griffing, B. (1956b). Concepts of general and specific combining ability in relation to diallel crossing systems. Australian Journal of Biological Sciences, 9, 463-493.

Gorjanovic, B. M., \& Kraljevic-Balalic, M. M. (2005). Inheritance of plant height and spike length in wheat. Genetika, 37, 25-31.

Habib, I., \& Khan, A. S. (2003). Genetic model of some economic traits in bread wheat (Titicum aestivum L.). Asian Journal of Plant Sciences, 2, 1153-1154.

Hayman, B. I. (1954a). The analysis of variance of diallel tables. Biometrics, 10, 235-244.

Hayman, B. I. (1954b). The theory and analysis of diallel crosses. Genetics, 39, 789-809. 
Hucl, P., \& Matus-Cadiz, M. (2002). CDC EMDR-4, CDC EMDR-9, and CDC EMDR-14 spring wheats. Canadian Journal of Plant Sciences, 82, 411-413.

Inamullah., Mohammad, F., \& Hassan, G. (2005). Genetics of important traits in bread wheat using diallel analysis. Sarhad Journal of Agriculture, 21, 617-622.

Iqbal, M., Navabi, A., Salmon, D. F., Yang, R. C., \& Spaner, D. (2006). A genetic examination of early flowering and maturity in Canadian spring wheats. Canadian Journal of Plant Sciences, 86(4), 995-1004. http://dx.doi.org/10.4141/P06-002

Iqbal, M., Navabi, A., Salmon, D. F., Yang, R. C., Murdoch, B. M., Moore, S. S., \& Spaner, D. (2007). Genetic analysis of flowering and maturity time in high latitude spring wheat. Euphytica, 154, 207-218. http://dx.doi.org/10.1007/s10681-006-9289-y

Jedel, P. E., Evans, L. E., \& Scarth, R. (1986). Vernalization responses of a selected group of spring wheat (Triticum aestivum L.) cultivars. Canadian Journal of Plant Sciences, 66, 1-9.

Jinks, J. L., \& Hayman, B. I. (1953). The analysis of diallel crosses. Maize Genetic Cooperation News, 27, 48-54.

Jinks, J. L. (1954). The analysis of continuous variation in a diallel cross of Nicotiana rustica varieties. Genetics, $39,767-788$.

Kamaluddin., Singh, R. M., Prasad, L. C., Abdin, M. Z., \& Joshi, A. K. (2007). Combining ability analysis for grain filling duration and yield traits in spring wheat (Triticum aestivum L. Em. Thell). Genetics and Molecular Biology, 30, 411-416. http://dx.doi.org/10.1590/S1415-47572007000300018.

Kato, H., Taketa, S., Ban, T., Irik.i, N., \& Murai, K. (2001). The influence of a spring habit gene, Vrn-D1, on heading time in wheat. Plant Breeding, 120, 115-120. http://dx.doi.org/10.1046/j.1439-0523.2001.00586.x

Kato, K., \& Wada, T. (1999). Genetic analysis and selection experiment for narrow-sense earliness in wheat by using segregating hybrid progenies. Breeding Science, 49, 233-238.

Khalifa, M. A. (1998). Genetics of earliness in bread and durum wheat. In A. E. Slinkard(ed.). Proceeding of the $9^{\text {th }}$ International Wheat Genetics Symposium. Saskatoon, Saskatchewan, Canada. 1, 256-257.

Klaimi, Y. Y., \& Qualset, C. O. (1974). Genetics of heading time in wheat (Triticum aestivum L.) II. The inheritance of vernalization response. Genetics, 76, 119-134.

Kosner, J., \& Pankova, K. (1998). The detection of allelic variants at the recessive vrn loci of winter wheat. Euphytica, 101, 9-16.

Kumar, A., Mishra, V. K., Vyas, R. P., \& Singh, V. (2011). Heterosis and combining ability analysis in bread wheat (Triticum aestivum L.). Journal of Plant Breeding and Crop Science, 3(10), 209-217.

Law, C. N., \& Worland, A. J. (1997). Genetic analysis of some flowering time and adaptive traits in wheat. New Phytologist, 137, 19-28.

Levy, J., \& Peterson, M. L. (1972). Responses of spring wheat to vernalization and photoperiod. Crop Science, $12,487-490$.

Mahmood, N., Chowdhry, M. A., \& Kashif, M. (2003). Genetic analysis of some physio-morphic traits of wheat under drought condition (Triticum aestivum L.). Pakistan Journal of Genetic and Breeding, 57, 385-391.

Nanda, G. S., Hazarika, G. N., \& Gill, K. S. (1981). Inheritance of heading date, plant height, ear length and spikelets per spike in an intervarietal cross of wheat. Theoretical and Applied Genetics, 60, 167-171. http://dx.doi.org/10.1007/BF00264523

Ojaghi, J., \& Akhundova, E. (2010). Genetic analysis for yield and its components in doubled haploid wheat. African Journal of Agricultural Research, 5(4), 306-315.

Poehlman, J. M., \& Sleper, D. A. (1995). Breeding field crops. Iowa State University Press, Ames Iowa USA, p. 151.

Riaz, R., \& Chowdhary, M. A. (2003). Genetic analysis of some economic traits of wheat under drought conditions. Asian Journal of Plant Sciences, 2, 790-796. http://dx.doi.org/10.3923/ajps.2003.790.796

Rahman, M. A., Siddquie, N. A., Alam, M. R., Khan, A. S., \& Alam, M.S. (2003). Genetic analysis of some yield contributing and quality characters in spring wheat (Triticum aestivum L.). Asian Journal of Plant Sciences, 2, 277-282. 
SAS Institute. (2003). Release 9.1. SAS Institute, Inc., Cary NC USA.

Shahzad, K., \& Chowdhry, M. A. (1998). Study of combining ability for plant height, yield and some leaf characteristics in bread wheat. Journal of Animal and Plant Sciences, 8(1), 23-25.

Sheikh, S., Singh, I., \& Singh, J. (2000). Inheritance of some quantitative traits in bread wheat (Triticum aestivum L. em Thell.). Annals of Agricultural Research, 21, 51-54.

Singh, H., Sharma, S. N., Sain, R. S., \& Singhania, D. L. (2003) The inheritance of production traits in bread wheat by diallel analysis. SABRAO Journal of Breeding and Genetics, 35, 1-9.

Singh, I., \& Paroda, R. S. (1986). Partial diallel analysis including parents for combining ability in wheat. Indian Journal of Genetics, 46, 490-495.

Slafer, G. A., \& Rawson, H. M. (1994). Sensitivity of wheat phasic development to major environmental factors: a re-examination of some assumptions made by physiologists and modelers. Australian Journal of Plant Physiology, 21, 393-426.

Snape, J. W., Sarma, R., Quarrie, S. A., Fish, L., Galiba, G., \& Sutka, J. (2001). Mapping genes for flowering time and frost tolerance in cereals using precise genetic stocks. Euphytica, 120, 309-315. http://dx.doi.org/10.1023/A:1017541505152

SPSS Inc. (2004). SPSS User's Guide. Ver. 14. SPSS Inc. Chicago, IL. USA.

Stelmakh, A. F. (1998). Genetic systems regulating flowering response in wheat. Euphytica, 100, 359-369. http://dx.doi.org/10.1023/A:1018374116006.

Ullah, S., Khan, A. S., Raza, A., \& Sadique, S. (2010). Gene action analysis of yield and yield related traits in spring wheat (Triticum aestivum). International Journal of Agriculture and Biology, 12, 125-128.

Ukai, Y. (2006). DIAL98. User's Guide. Ver. 6. DIAL98. Japan.

Worland, A. J. (1996). The influence of flowering time genes on environmental adaptability in European wheats. Euphytica, 89, 49-57.

Xiang, B., \& Li, B. (2001). A new mixed analytical method for genetic analysis of diallel data. The Canadian Journal for Research, 31, 2252-2259.

Yan, W., \& Hunt, L. A. (2002). Biplot analysis of diallel data. Crop Science, 42, 21-30.

Zhang, H., Jiujiang, Y., Kongge, W., \& Xiangke, Z. (1985). Studies on the inheritance of earliness and its selection in bread wheat (T. aestivum L.). Acta Botanica Boreali-occidentalia Sinica. Available at: http://en.cnki.com.cn/Article_en/CJFDTOTAL-.DNYX198503006.htm 